\title{
Late Gadolinium Enhancement does occur in the Tako-Tsubo Cardiomyopathy - a quantitative cardiovascular magnetic resonance study
}

Christian Hamilton-Craig ${ }^{1 *}$, Kris Nowakowski ${ }^{2}$, Nick J Brett ${ }^{1}$, Wendy E Strugnell ${ }^{1}$, Richard E Slaughter ${ }^{1}$

From 2011 SCMR/Euro CMR Joint Scientific Sessions

Nice, France. 3-6 February 2011

\section{Background}

Tako-tsubo cardiomyopathy (TTC) accounts for $1 \%$ of admissions for chest pain in Japan and up to 1 in 30 cases referred for acute primary angioplasty in Western cohorts.

The absence of myocardial late gadolinium enhancement (LGE) on cardiac magnetic resonance imaging (CMR) has been recommended in the literature to distinguish TTC from either acute myocardial infarction or myocarditis.



Figure 1 A) angiography, B) ventriculography, C) systolic SSFP 4chamber frame, D) quantitative LGE plot.

${ }^{1}$ Centre of Excellence in Cardiovascular MRI, Brisbane, Australia

Full list of author information is available at the end of the article

(c) 2011 Hamilton-Craig et al; licensee BioMed Central Ltd. This is an open access article distributed under the terms of the Creative 


\section{Method}

Data were retrospectively reviewed from 27 consecutive patients with confirmed Mayo Clinic criteria for TTC (clinical, ECG, angiographic and left ventriculographic findings) presenting to our institution over a 2 year period. A CMR (GE 1.5T Twinspeed) protocol of steady state free precession, triple inversion recovery, and myocardial LGE imaging was performed in the acute phase. LGE was quantified using standardized software (ReportCard V4.0), with both 2 and 5 standard deviations thresholds (SD) above normal remote myocardium, normalized to LV mass.

\section{Findings}

All patients had raised serum troponin I (mean $3.7 \mathrm{ug} / \mathrm{mL}$, range $0.2-30$ ). Mean ejection fraction by CMR was $43 \%$ $\pm 8.5 \%$ (range $25-51 \%$ ), mean door-to-CMR time 59 hours. All patients had significantly abnormal wall motion; apical ballooning in 18 and midwall variant in 9 cases. Eleven patients (41\%) had diffuse LGE localized to the area of abnormal wall motion, representing $34.5 \pm 9 \%$ LV mass. In 9 of these 11 patients, LGE signal intensity was $>5$ SD above normal myocardium, representing $16.5 \pm 12 \% \mathrm{LV}$ mass. This has not been previously described. Those with $>5$ SD LGE had raised LV volumes and reduced EF $(\mathrm{p}=0.047)$. Mean troponin trended to higher levels in LGE positive patients $(2.31 \pm 1.8$ vs $4.69 \pm 8.6, \mathrm{p}=0.10)$. The pattern of LGE differed to that seen in both ischemia and myocarditis. Improvement in segmental function was confirmed by follow-up CMR or echocardiography in all patients. Figure 1

\section{Conclusion}

In this single-center series, LGE was present in $41 \%$ of cases of TTC, occurring in a diffuse pattern through the areas of myocardial stunning, $82 \%$ of which were $>5$ SD above normal myocardium. This likely represents diffuse myocyte damage. Absence of LGE should not, therefore, be used as a diagnostic criterion for TTC. LGE does occur in the takotsubo cardiomyopathy, and presence of intense ( $>5 \mathrm{SD}$ ) LGE appears associated with worse myocardial injury.

\section{Author details}

${ }^{1}$ Centre of Excellence in Cardiovascular MRI, Brisbane, Australia. ${ }^{2}$ Department of Cardiology, Prince Charles Hospital, Brisbane, Australia.

Published: 2 February 2011

doi:10.1186/1532-429X-13-S1-P314

Cite this article as: Hamilton-Craig et al.: Late Gadolinium Enhancement

does occur in the Tako-Tsubo Cardiomyopathy - a quantitative

cardiovascular magnetic resonance study. Journal of Cardiovascular

Magnetic Resonance 2011 13(Suppl 1):P314.
Submit your next manuscript to BioMed Central and take full advantage of:

- Convenient online submission

- Thorough peer review

- No space constraints or color figure charges

- Immediate publication on acceptance

- Inclusion in PubMed, CAS, Scopus and Google Scholar

- Research which is freely available for redistribution 